\title{
SELECTION OF THE DISTANCE LEARNING MANAGEMENT SYSTEM FOR PEDAGOGICAL HIGHER EDUCATION INSTITUTIONS
}

\author{
Oleksii Mukoviz \\ Doctor in Pedagogical Sciences, Professor of Theory of Primary Education Chair \\ Pavlo Tychyna Uman State Pedagogical University, Uman, Ukraine \\ alexsmukovoz@gmail.com \\ ORCID: 0000-0001-9262-9209
}

\section{Nataliia Ihnatenko}

Ph.D. in Pedagogical Sciences,

Professor of Department of Pedagogy, Theory and Methods of Primary Education, Dean of Pedagogical Faculty SHEI «Pereiaslav-Khmelnytskyi Hryhorii Skovoroda State Pedagogical University», Pereiaslav-Khmelnytskyi, Ukraine

i.natalvik@gmail.com,phdpu_ped_fak@ukr.net

ORCID: 0000-0003-1616-8708

\section{Oksana Kovtun}

Ph.D. in Pedagogical Sciences,

Associate Professor of Department of Pedagogy, Theory and Methods of Primary Education, Head of Department of International Relations

SHEI «Pereiaslav-Khmelnytskyi Hryhorii Skovoroda State Pedagogical University», Pereiaslav-Khmelnytskyi, Ukraine

kovtunok@ukr.net

ORCID: 0000-0002-9516-8628

\begin{abstract}
The article deals with various distance learning management system for pedagogical higher education institution. The most prominent distance learning management systems are mostly focused on: Moodle, WebCT, BlackBoard, eFront, Claroline, Metacoon, SharePoint LMS and Virtual University. Having analyzed the best platforms for creating of distance learning system in pedagogical higher education institution, it is stated that Moodle is leading according to the number of users. Moodle platform is a software suite for creating distance learning courses and websites that works with open source IMS and SCORM. As a result of the analysis and comparisons of the abovementioned platforms, based on pedagogical, didactic, organizational, technical, financial distance learning features, the distance learning management system in State Higher Educational Institution «Pereiaslav-Khmelnytskyi Hryhorii Skovoroda State Pedagogical University» on the basis of Moodle platform is developed. The platform works in different web browsers. There are no special requirements for hardware and operating system. Moodle platform can be installed on any server with any operating system using arbitrary databases. The platform is free for users. Moodle distance learning management system consists of 35 modules: Chat module, Task module, Forum module, Log module, Test module, Resource module, Research module, Seminar module and so on. Moodle distance learning management system enables distance learning in higher education at an affordable innovation level, creates a calendar of learning process events, creates formal algorithms for the teacher's activity in the educational process, thereby achieving a high level of interactivity and achievement of the required level of quality, skills.
\end{abstract}

Keywords: distance learning; distance learning management system; into the pedagogical higher education institution

Formulation of the problem. The rapid development of information and communication technologies makes it possible to modernize and improve the efficiency of education, to automate the educational process. By integrating innovative technologies into the higher education institution's educational process, the prerequisites for the introduction of distance education, based on the use of information and communication technologies, provide the necessary level of improvement of students' knowledge. This form allows you to gain 
knowledge without constantly attending a school, and allows for continuous professional development throughout your life.

Analysis of recent research. The theoretical and methodological basis of distance learning was first developed in Ukraine by scientists of the Institute of Information Technologies and Learning Tools of the National Academy of Educational Sciences of Ukraine (V. Y. Bykov, O. M. Spirin, M.P. Shyshkina, etc.). Various aspects of the organization of distance vocational education have become the subject of research by L. A. Kartashova, H.O. Kozlakova, V. V. Oliinyk, Zh. V. Talanova and others. Teacher training in the distance learning system was investigated by V. O. Gravit, V. V. Oliynyk, I. V. Stetsenko, Y. V. Trius and others.

The results of a special scientific search in the field of teaching staff training by means of distance learning are reflected in the dissertations O. M. Alekseev, Y. V. Heiko, I. V. Herasimenko, T. V. Hrigorchuk, N. V. Zhevakina, K. R. Kolos, E. M. Smirnova-Tribulskaya, O. V. Khmel and others.

However, the problem of the effectiveness of the technical functioning of the distance learning system for a pedagogical institution of higher education has not yet been the subject of a comprehensive analysis of scientists.

The purpose of the article is to analyze a number of learning management systems and determine the most optimal one for organizing distance learning in a pedagogical institution of higher education.

Presenting main material. The modern distance learning management system must meet the organizational and technical needs: to support the work of the software on any network, on any platform, to have Internet-compatible interface and to store data in a standardized format of storage of educational information (Bykov, 2008).

The parameters of the distance learning management system must also meet the requirements of international standards IMS, SCORM for the DN system, in particular for profile distance learning courses (Kravtsov, 2009).

There are many distance management systems different in technical capabilities, availability and complexity of various functional components, range of use, price and pricing, equipment requirements, including commercial products, such as WebCT, BlackBoard, eFront, Metacoon, SharePoint LMS, Virtual University, etc., and freely distributed: Moodle, Claroline, etc. More modest is the list of platforms that support all stages of the pedagogical process, whereas when choosing a system, the didactic aspect must be decisive.

Let us analyze them in detail.

1. Moodle (developer: MOODLE PTY, Australia) - (from English - modular-dynamic, object-oriented environment for learning) a software module for creating open-source IMS remote courses and websites and SCORM.

Moodle can be installed on any computer that supports PHP and works with DBMS MySQL, PostgreSQL, Microsoft SQL Server.

The platform is managed by an administrator who is assigned during the installation and contains the following elements: dynamic interface themes (adjusting colors, fonts, layout of interface elements, etc.); a large number of modules to extend functionality; wide choice of languages in the interface (35 languages, including Ukrainian); program code available for editing.

Statistics show that about 130 Moodle websites, 4 million users and 350,000 distance courses are already registered today. This confirms that the platform has been used successfully all over the world, is user-friendly and up-to-date, and has a toolbox that allows it to be edited. 
2. WebCT (Developer: University of British Columbia, Canada) is a client-server elearning platform that supports relational database management. It provides tools for developing online courses, self-testing, and student testing. But this platform has several disadvantages as well: there is no possibility to create individualized training plans (for user, group of users), there are no results of training in electronic information and in personal business, there is no account for organization and holding of web conferences, reports, lectures, training seminars and more. The license is issued for one year. The cost of the license is $\$ 4000$, depending on the number of client sites.

The WebCT-based distance learning system has been successfully used by the University of Texas (USA), McGill (Canada) and others. But recently, WebCT is technically outdated and not being improved.

3. BlackBoard (developer: BlackBoard Inc., USA) is a modular-educational portal that provides organization of interactive learning, interaction and exchange of information between students and teachers. The platform can create virtual training courses, interactive complexes, provide remote access to educational resources of other educational institutions, control the educational process, structure, manage access, replenish the training base, and organize real-time communication between participants. The downside is the price. License is granted for 12 months. The cost is related to the number of users - from about $\$ 38,000$.

The BlackBoard-based distance learning system has been successfully used in commercial educational institutions in 60 countries, including Cornell University (USA), one of the largest US universities.

4. eFront (developer: company EPIGNOSIS LTD, Greece) - modular web-based platform for the organization of educational process in institutions of higher education, as well as for professional development, appraisal and selection of employees in different organizations. eFront translated into 41 languages and has the ability to attract to learning technology Wiki, RSS, chat, discussion forums and various types of test, learning tasks in standard MS Office and pdf. The graphical interface of the platform reflects the dynamics of the learning process, making use extremely comfortable. eFront the basic version (Community Edition) is free open source. Some of the features of the platform are certified to support SCORM format. The concept of learning used in eFront, aimed at attracting customers and maintaining their interest.

The system of distance learning platform eFront successfully used in the Ministry of internal Affairs of Poland, in commercial companies and state educational institutions in the USA, Greece, Australia.

5. Claroline (developer: CERDECAM research center, Belgium) is a modular platform with open source. Distributed based on GNU General Public License. Has a simple interface with support for 35 languages.

The system of distance learning platform Claroline is successfully used at major universities in Europe, Canada and Latin America.

6. Metacoon (developer: Ventis company Meta, Germany) is a modular platform, based on the principle of virtual desktop with which students and teachers can get quick access to the messaging system, class schedules, list of academic disciplines, photo galleries, calendar of events, etc.

The system of distance learning platform Metacoon is used successfully at the University of Weimar (Germany) and other educational institutions of Europe.

7. SharePoint LMS (developers: Microsoft, USA and Learningforce, Denmark) is a modular platform based on Microsoft SharePoint technology. It provides a variety of software tools for creating training courses and tests, as well as a converter that allows you to import courses from other systems. 
The SharePoint LMS platform-based e-learning system has been successfully used at Royal University, South Cheshire College (UK) and other educational institutions.

8. Virtual University (developer: team of the project «Distance Learning System Virtual University», Ukraine) is a corporate-level platform designed for organizing distance learning for employees of companies and educational institutions of all sizes and levels.

Virtual University runs on any operating system that is installed on the server.

It is based on the following principles: hierarchy, modularity, parallelism, remoteness, coverage of many sources of educational information, efficiency, adaptability, social equality, objectivity of knowledge assessment.

The platform has a simple interface that can be understood by the user even with low computer literacy.

The organization of the educational process uses a modular-information principle, using the information-logical scheme of the discipline and displaying links with modules of other disciplines that provide it.

The online library of the platform provides access to any materials and documents.

Chat, forums, blogs are organized for the dialogue between the teacher and students or between students.

The system of distance learning based on the Virtual University platform has been successfully implemented at the National Technical University of Ukraine KPI, Berdyansk Management and Business University, etc.

Table 1 will help to summarize the comparative characteristics of distance learning management systems.

Table 1.

Comparative characteristics of distance learning management systems

\begin{tabular}{|c|c|c|c|c|c|c|c|c|c|}
\hline \multirow{2}{*}{$n^{\text {Non/ }}$} & \multirow[t]{2}{*}{ Parameter } & \multicolumn{8}{|c|}{$\begin{array}{l}\text { Learning Management } \\
\text { System Number }\end{array}$} \\
\hline & & 1 & 2 & 3 & 4 & 5 & 6 & 7 & 8 \\
\hline 1. & Successful use in educational institutions & + & + & + & + & + & + & + & + \\
\hline 2. & Integration with user information environment & + & + & - & + & + & - & + & + \\
\hline 3. & Open source code & + & - & - & - & + & - & - & - \\
\hline 4. & Availability of tools for creating courses & + & + & - & + & + & - & + & + \\
\hline \multirow{2}{*}{5.} & Support for SCORM standards courses & + & + & - & + & + & - & + & + \\
\hline & and IMS & + & + & + & + & + & + & + & + \\
\hline 6. & Modular structure & + & + & + & + & + & + & + & + \\
\hline 7. & Web-oriented structure & + & + & + & + & + & + & + & + \\
\hline 8. & Service support & + & - & + & + & + & + & + & + \\
\hline 9. & Ukrainian-language interface & + & - & - & + & + & - & - & + \\
\hline 10. & $\begin{array}{l}\text { Methodological and pedagogical features are taken } \\
\text { into account }\end{array}$ & + & - & - & + & - & - & - & + \\
\hline 11. & $\begin{array}{l}\text { Use of different types of fonts, drawings, } \\
\text { animations, video broadcasts, etc. }\end{array}$ & + & + & + & + & + & + & + & + \\
\hline \multirow{5}{*}{12.} & Availability of communication means: & + & + & + & + & + & + & + & + \\
\hline & text messaging; & + & + & + & + & + & + & + & + \\
\hline & file sharing; & + & + & + & + & + & + & + & + \\
\hline & forums; & + & - & + & + & + & + & + & + \\
\hline & video chat. & + & - & + & + & + & + & + & + \\
\hline
\end{tabular}


Having analyzed the best platforms for creating distance learning system in pedagogical higher education institution we found out that Moodle is leader according to the number of users.

As a result of analysis and comparisons of the above platforms, based on pedagogical, didactic, organizational, technical, financial features of distance learning, we have developed a system of distance learning of the State Higher Education Institution «PereiaslavKhmelnytskyi Hryhorii Skovoroda State Pedagogical University» using the Moodle platform (http://moodle.g35.info). Let's analyze it in more detail.

The platform works in a web browser. There are no special requirements for hardware and operating system. It is completely free. It is installed on any server, with any operating system using arbitrary databases.

E. M. Smirnova-Trybulska, considering the organization of the educational process in the system of distance learning on the Moodle platform, identifies the components and connections that should be maintained in the institution of higher education through the mechanisms of the system of distance learning. System maintenance should not cause any problems for users. Therefore, it is advisable for the system to be served using a web browser by students, teachers, developers and authors of the course, administrators (SmirnovaTribulska, 2008).

Moodle's distance learning management system consists of 35 modules. Let's analyze the main of them:

1. Chat module allows for simultaneous, smooth text interaction between participants of the educational process with the inclusion of pictures; support emoticons, embedded HTML, pictures, etc; view chatting.

2. The Task Module enables students to download teacher-scheduled tasks from the server (in any file format); review and evaluate tasks; perform tasks with exceeding the time limit (the student reports the delay to the teacher); re-perform the task after the evaluation.

3. The forum module allows you to choose different types of forums (teacher forum, course news forum, forum for all users, one-threaded user forum); view discussions according to time, sequence; adjust discussions by comparing opinions of users in different forums.

4. The log module provides the ability to ensure the privacy of each user; set aside separate pages for each training group; create students' own pages based on an open-ended question posed by the teacher; attach the teacher's feedback to the page and send the appropriate message.

5. The test module allows the teacher to fill the platform template with different groups of tasks; divide tests into categories by access level; perform automatic evaluation of tests; set the time of completion of test tasks; protect responses from write-offs; support HTML format and images; download tests from an external text file; limit the number of attempts to test.

6. The resource module provides access to Web resources; compatibility with common applications (Word, Excel, PowerPoint, Flash, Windows Media, etc.); manage server files created using Web forms.

7. The research module has built-in studies (COLLES, ATTLS) of online classes; provides access to related research.

8. The seminar module allows the teacher to manage the process of execution and to check the assignments; automatically determine the rank of each student; choose templates for the task-solving algorithm.

The course setting allows the teacher to:

- to choose courses depending on the schedule and topic; 
- to organize the educational process in the chosen discipline by different means (forums, magazines, resources, research, tasks, chats, seminars, tests);

- to change the home page;

- to edit the text using the built-in HTML editor;

- to review and evaluate in a separate file the results of student participation in forums, tests, tasks;

- to have full access to user activity reports, including time spent on various types of work, systems from each module; replies;

- to keep HTML and plain text copies of the posts in the forums and the teachers'

- to vary students' knowledge assessment systems;

- to archivate courses.

It is important to emphasize that Moodle is developing very fast. Groups of experts from different countries (including Ukraine, Poland, Australia, Nigeria, Cuba, Czech Republic, Canada, etc.) test and evaluate new versions of the platform, offer concepts for its development, share experience in pedagogical theory and practice.

Conclusions. Therefore, the Moodle distance learning management system enables distance learning in higher education at an affordable innovation level, to create a calendar of learning process events, to create formalized algorithms of the teacher's activity in the educational process, thereby achieving a high level of interactivity and achievement of the required level of interactivity knowledge, skills.

In our opinion, the chosen distance learning management system contributes to the fundamentalization of education, the development of e-learning, the study of theoretical, methodological and practical problems of formation, functioning and development of the system of lifelong education, ensures the formation of the future specialists' readiness for implementation of DN in their own system of lifelong education.

Prospects for further researches include the development and implementation of distance learning courses in all forms of organization of the educational process of pedagogical higher education institution using a modern distance learning management system on the Moodle platform.

\title{
REFERENCES
}

Bykov, V.Y. (2008). Models of organization of open education systems: monograph. Kyiv: Atika, 684 (in Russian)

Kravtsov, H. (2009). Evaluation Metrics of Electronic Learning Resources Quality. Informational Technologies in Education: Scientific Journal, 3, 141-147 (in Russian)

Smirnova-Tribulska, E.M. (2008). Distance learning using the MOODLE system: theoretical and practical aspect. Information technologies in education, 1, 145-154 (in Ukrainian)

\section{ВИБІР СИСТЕМИ УПРАВЛІННЯ ДИСТАНЦЙННИМ НАВЧАННЯМ ДЛЯ ПЕДАГОГІЧНОГО ЗАКЛАДУ ВИЩОЇ ОСВІТИ}

\author{
Муковіз Олексій Павлович \\ Доктор педагогічних наук, професор кафедри теорії початкового навчання \\ Уманський державний педагогічний університет імені Павла Тичини, Умань, Україна \\ alexsmukovoz@gmail.com \\ ORCID: 0000-0001-9262-9209
}


ISSN: 2414-0325. Open educational e-environment of modern University, special edition (2019)

\title{
Ігнатенко Наталія Вікторівна
}

Кандидат педагогічних наук, професор кафедри педагогіки, теорії і методики початкової освіти, декан педагогічного факультету

ДВНЗ «Переяслав-Хмельницький державний педагогічний університет імені Григорія Сковороди», Переяслав-Хмельницький, Україна

i.natalvik@gmail.com,phdpu_ped_fak@ukr.net

ORCID: 0000-0003-1616-8708

\section{Ковтун Оксана Анатоліївна}

Кандидат педагогічних наук, доцент кафедри педагогіки, теорії і методики початкової освіти, керівник відділу міжнародних зв'язків

ДВНЗ «Переяслав-Хмельницький державний педагогічний університет імені Григорія Сковороди», Переяслав-Хмельницький, Україна

kovtunok@ukr.net

ORCID: 0000-0002-9516-8628

\begin{abstract}
Анотація. У статті розглянуто різноманітні системи управління дистанційним навчанням для педагогічного закладу вищої освіти. Переважно звернуто увагу на найвідоміші системи управління дистанційним навчанням: Moodle, WebCT, BlackBoard, eFront, Claroline, Metacoon, SharePoint LMS та Віртуальний Університет. Аналізуючи кращі платформи для створення системи дистанційного навчання педагогічного закладу вищої освіти, ми встановили, що лідерами за кількістю користувачів є Moodle. Moodle - програмний комплекс для створення дистанційних курсів та web-сайтів, який працює з відкритим кодом IMS та SCORM. У результаті аналізу та порівнянь вище вказаних платформ, керуючись педагогічними, дидактичними, організаційними, технічними, фінансовими особливостями дистанційного навчання, розроблено систему управління дистанційним навчанням Державного вищого навчального закладу «Переяслав-Хмельницький державний педагогічний університет імені Григорія Сковороди» за допомогою платформи Moodle. Платформа працює у web-браузері. Не передбачає ніяких спеціальних вимог до устаткування та операційної системи. $€$ повністю безкоштовною. Інсталюється практично на будь-якому сервері, з будь-якою операційною системою із використанням довільних баз даних. Система управління дистанційним навчанням на платформі Moodle складається із 35 модулів: модуль чату, модуль завдань, модуль форуму, модуль журналів, модуль тестів, модуль ресурсів, модуль дослідження, модуль семінарів тощо. Система управління дистанційним навчанням на платформі Moodle надає можливість здійснювати дистанційну освіту у закладі вищої освіти на доступному інноваційному рівні, формувати календар подій процесу навчання, створювати формалізовані алгоритми діяльності викладача у навчальному процесі, тим самим, досягти високого ступеня інтерактивності та досягнення необхідного рівня якості знань, вмінь.
\end{abstract}

Ключові слова: дистанційне навчання; система управління дистанційним навчанням; в педагогічний заклад вищої освіти 